\title{
HÁ CRISE DE CRIATIVIDADE NA DRAMATURGIA? ${ }^{1}$
}

\section{O remake de telenovelas é o recurso que as redes de televisão têm}

acionado para planejar e reduzir custos, garantindo audiência sem correr maiores riscos

A Rede Globo está apresentando no horário das $18 \mathrm{~h}$ mais um remake, Os irmãos Coragem, telenovela de Janete Clair de grande sucesso no início da década de 70. A emissora transmitiu uma versão de A viagem, de Ivani Ribeiro, no horário das 19h. Por outro lado, exibiu Sonho meu, no horário das $18 \mathrm{~h}$, uma fusão de duas antigas telenovelas de Teixeira Filho, A pequena órfã (TV Excelsior, 1968-1969) e Ídolo de pano (TV Tupi, 1974-1975).

Deve-se ainda mencionar dois outros remakes realizados pela Rede Globo nos últimos anos: em 1989-1990, O sexo dos anjos, de Ivani Ribeiro, exibida anteriormente pela TV Excelsior em $1968 \mathrm{com}$ o nome de $O$ terceiro pecado; em 1993 Mulheres de areia, de Ivani Ribeiro, representou uma versão ampliada de uma teleno-

\section{A AUTORA}

Anamaria Fadul

Professora Doutora do Departamento de Comunicações e Artes da ECA-USP e Coordenadora Geral do Núcleo de Pesquisa da Telenovela do Departamento de Comunicaçôes e Artes da ECA-USP. vela de 1973-1974, incluindo tramas de uma outra telenovela da mesma autora, $\mathbf{O}$ espantalho.

Mas essa não é somente uma realidade da Rede Globo. O SBT exibiu Éramos seis, de Rubens Ewald Filho e Sílvio de Abreu, baseada na obra homônima de Maria José Dupré, que já havia tido duas outras adaptações anteriores realizadas pela TV Tupi em 1967 e 1977. No final de dezembro de 1994 entrou no ar uma outra versão de As pupilas do Senhor Reitor, de Lauro César Muniz, já apresentada pela TV Record em 1970-1971.

Os remakes, apesar de fazerem parte da história da telenovela, não são uma especificidade desse gênero de ficção. Também no teatro e no cinema existe essa prática de se refazer antigas montagens teatrais e produções cinematográficas.

O que se deve tentar compreender é o porquê da intensificação dessa tendência na década de 90 , num momento em que a telenovela brasileira atingiu um desenvolvimento que atesta sua maturidade enquanto gênero televisivo específico. 
Existem várias hipóteses para esse fenômeno dos remakes. Em primeiro lugar, é preciso considerar o início de uma maior competitividade entre as redes de televisão na década de 90 , caracterizando em alguns casos uma verdadeira guerra de audiência, o que dificulta o surgimento de projetos completamente inovadores. Em segundo lugar, o agravamento da crise econômica levou as emissoras a uma maior cautela com relação a grandes investimentos em obras ainda não testadas junto ao público telespectador. Por último, mas não menos importante, não se estaria vivendo um período de crise de criação na área de dramaturgia? Essa última pergunta só poderia ser respondida pelos próprios autores que têm refletido sobre os rumos da telenovela desde sua constituição como um gênero específico da indústria televisiva brasileira. 